Ellakd, G. A. \& Crarke, P. H. (1959). J. gen. Microbiol. 21, 338-343

\title{
Acetate and Fumarate Permeases of Mycobacterium smegmatis
}

\author{
By G. A. ELLARD* and PATRICIA H. ClARKE \\ Biochemistry Department, University College London
}

\begin{abstract}
SUMMARY: Mycobacterium smegmatis was grown on Lemco agar in the presence and absence of acetate and fumarate. Fumarate was oxidized rapidly by fumarategrown organisms. Lemco-grown and acetate-grown organisms oxidized fumarate at an increasing rate after a lag period and this adaptation was inhibited by chloramphenicol. Disrupted bacterial preparations oxidized fumarate rapidly, irrespective of the growth medium. Acetate-grown organisms oxidized acetate at more than twice the rate of fumarate-grown and Lemco-grown organisms. There was slight adaptation to acetate oxidation by acetate-grown organisms but greater adaptation by Lemeo-grown and fumarate-grown organisms. Acetate was oxidized by disrupted bacterial preparations. The evidence for the existence of acetate and fumarate permeases is discussed.
\end{abstract}

Recent studies have suggested that organic molecules may enter the bacterial cell by the action of specific transport mechanisms. Cohen \& Monod (1957) reviewed the evidence for the existence of stereo-specific permeases in Escherichia coli and other organisms. Shilo \& Stanier (1957) found that there were adaptive specific transport mechanisms for the three tartrate stereoisomers oxidized by pseudomonads. Clarke \& Meadow (1959) suggested that there are adaptive permeases for the acids of the tricarboxylic acid cycle in Pseudomonas aeruginosa. Millman \& Youmans (1955) found that all the necessary enzymes of the tricarboxylic acid cycle could be demonstrated in cellfree extracts of Mycobacterium tuberculosis, although few of the substrates could be oxidized by whole organisms. The impermeability of mycobacteria to many compounds which are normal cell metabolites, has long been thought to be related to the high lipid content of the cell wall. This investigation was designed to test the hypothesis that the impermeability of mycobacteria might be due to the absence of specific permeases, and to this end the oxidation of acetate and fumarate by $M$. smegmatis was studied.

\section{METHODS}

Mycobacterium smegmatis NCTC 8159 was obtained from the National Collection of Type Cultures. It was maintained by weekly subculture on slopes of Lemco agar (10 g. peptone; $10 \mathrm{~g}$. Lab. Lemco; $5 \mathrm{~g} . \mathrm{NaCl} ; 10 \mathrm{~g}$. agar; water to 1 l.; pH 7.6). Cultures incubated for $24 \mathrm{hr}$. in Lemco broth were used to inoculate Roux bottles each containing $100 \mathrm{ml}$. Lemco agar. Good growth was obtained after 2 days at $87^{\circ}$, but longer incubation produced more mucoid cells which were difficult to handle. After incubation, the bacteria

* Present address : The East African Leprosy Research Centre, Busia, Uganda. 
were washed off the surface of the agar with about $100 \mathrm{ml}$. distilled water, centrifuged at $10,000 \mathrm{~g}$ for $5 \mathrm{~min}$. and washed once with the same volume of distilled water. The organisms from four Roux bottles were resuspended in 0.05 M Sørenson's phosphate buffer $(\mathrm{pH} 7 \cdot 6)$ and stirred mechanically to give a uniform suspension of 25-30 ml. for each series of experiments. Batches of organisms were also prepared which had been grown on Lemco agar to which either sodium acetate or sodium fumarate had been added to a final concentration of $0.4 \%(\mathrm{w} / \mathrm{v})$.

Suspensions were calibrated by measuring the optical density of suitable dilutions in an EEL (Evans Electroselenium Ltd.) colorimeter, and referring to a standard curve relating optical density to dry weight. Bacteria were disrupted by forcing the stock suspension through a small aperture at 4,000 lb./ sq.in. in a bacterial press modified from an apparatus described by Milner, Lawrence \& French (1950).

Manometric studies were carried out by the conventional Warburg technique. Flasks contained the equivalent of 2-4 $\mathrm{mg}$. dry wt. of bacteria, or of 6-16 mg. dry wt. disrupted bacteria in $1 \mathrm{ml}$. 0.05 M-phosphate buffer pH 7.6. Substrate solution (0.4 ml. $4 \%, \mathrm{w} / \mathrm{v}, \mathrm{Na}$ salt) was added from the sidearm, and where required, $0.2 \mathrm{ml}$. chloramphenicol solution $(1 \mathrm{mg} . / \mathrm{ml}$.) was added to the main flask and the volume made up to $3 \mathrm{ml}$. with the phosphate buffer; $0.2 \mathrm{ml}$. KOH $(30 \%, w / v)$ was added to the centre well. Experiments were carried out in duplicate and the figures given are means.

\section{RESULTS}

It was found that the rate of oxidation of acetate and fumarate by washed suspensions of Mycobacterium smegmatis depended on whether or not these compounds had been added to the growth medium. Organisms grown on Lemco agar showed adaptation to both acetate and fumarate oxidation. The initial rate of oxidation of acetate, and the linear rate in the presence of chloramphenicol were fairly high, but for fumarate the initial rate of oxidation and the rate in the presence of chloramphenicol were no greater than the endogenous rates. When the organisms were grown on acetate, the rate of acetate oxidation in the presence of chloramphenicol was more than twice that of the Lemco-grown organisms. In the absence of chloramphenicol, the rate of oxidation increased during the experimental period, but this increase was much less than with the Lemco-grown organisms. The acetate-grown organisms oxidized fumarate at a significant rate even in the presence of chloramphenicol, and the adaptation to fumarate oxidation in the absence of chloramphenicol, was much more rapid.

Organisms grown on fumarate oxidized fumarate rapidly at a constant rate from zero time, and the rate was not altered by the addition of chloramphenicol. Presumably therefore no adaptation to substrate was occurring. The fumarate-grown organisms oxidized acetate less rapidly than the acetate-grown organisms and there was some adaptation to acetate oxidation. The results for a typical series of experiments with whole organisms are shown 
in Fig. $1(a-c)$. There was some variation in activity with different batches of bacteria but this pattern of adaptive behaviour was consistent, except that after longer growth (3-4 days) on acetate agar, some batches of bacteria were found to oxidize acetate at a linear rate both in the presence and absence of chloramphenicol.

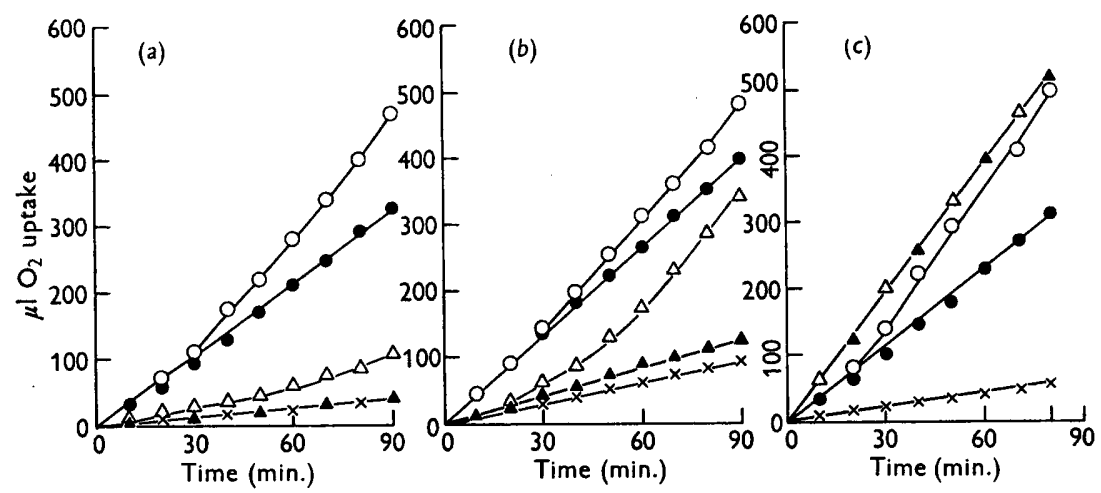

Fig. 1. Oxygen uptake by washed suspensions of Mycobacterium smegmatis; (a) Lemcogrown (1.2 mg. dry wt. $/ \mathrm{ml}$.); (b) acetate-grown (1.3 mg. dry wt./ml.); (c) fumarate grown ( $0.8 \mathrm{mg}$. dry wt. $/ \mathrm{ml}$.). $\times-\times$, no substrate; $\mathrm{O}-\mathrm{O}$, acetate; - , acetate + chloramphenicol; $\triangle-\triangle$, fumarate; $\Delta-\Delta$, fumarate + chloramphenicol.

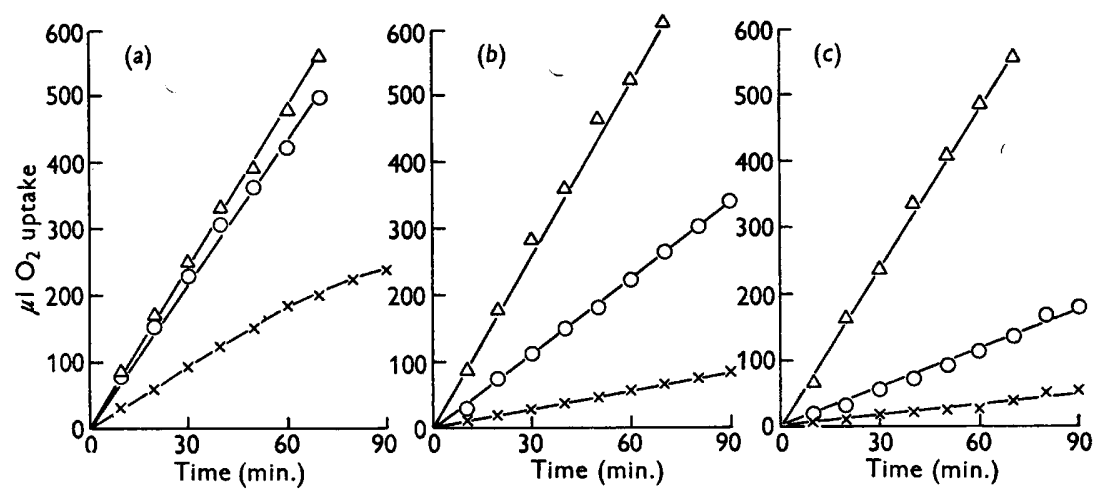

Fig. 2. Oxygen uptake by disrupted bacterial preparations of Mycobacterium smegmatis. (a) Lemco-grown (6 mg. dry wt./ml.); (b) acetate-grown (3.2 mg. dry wt./ml.); (c) fumarate-grown $(4.1 \mathrm{mg}$. dry wt. $/ \mathrm{ml}$.). $x-x$, no substrate; $0-0$, acetate; $\Delta-\Delta$, fumarate.

The whole organisms were compared with preparations which had been disrupted in the press. Some of the enzymes of the tricarboxylic acid cycle were found by Millman \& Youmans (1955) to be associated with the particulate fractions of mycobacterial extracts. With our disrupted bacterial preparations about $70 \%$ of the acetate-oxidizing system was removed by centrifugation at $10,000 \mathrm{~g}$ for $10 \mathrm{~min}$., so for these studies we used the completely disrupted bacterial preparation without removing cell debris or remaining whole organisms. Fig. $2(a-c)$ shows that acetate and fumarate were oxidized at a constant 
rate by disrupted bacterial preparations from organisms grown on all three media. The rate of fumarate oxidation was always higher than the rate of acetate oxidation, irrespective of the oxidative activity of the corresponding whole organisms. Chloramphenicol had no effect on the rate of fumarate oxidation by the disrupted bacterial preparations but there was a slight inhibition of acetate oxidation after $\mathbf{4 0} \mathrm{min}$.

Table 1 summarizes the results obtained for $Q_{0}$, with acetate and fumarate as substrates by whole organisms and disrupted preparations in the first $60 \mathrm{~min}$. The method of preparation of the disrupted bacteria always resulted in loss

Table 1. The oxidation of acetate and fumarate by Mycobacterium smegmatis

Substrate added to growth medium

\begin{tabular}{|c|c|}
\hline None & $\begin{array}{l}\text { Whole bacteria } \\
\text { Disrupted bacteria }\end{array}$ \\
\hline Acetate & $\begin{array}{l}\text { Whole bacteria } \\
\text { Disrupted bacteria }\end{array}$ \\
\hline Fumarate & $\begin{array}{l}\text { Whole bacteria } \\
\text { Disrupted bacteria }\end{array}$ \\
\hline
\end{tabular}

\begin{tabular}{|c|c|c|c|c|}
\hline $\begin{array}{c}\text { No } \\
\text { sub- } \\
\text { strate } \\
\text { l. } \mathbf{O}_{2}\end{array}$ & $\begin{array}{l}\text { Acetate } \\
\text { ng. bacte }\end{array}$ & $\begin{array}{c}\text { Ace- } \\
\text { tate+ } \\
\text { chloram- } \\
\text { phenicol } \\
\text { rial prepa }\end{array}$ & $\begin{array}{l}\text { Fuma- } \\
\text { rate } \\
\text { ration/0 }\end{array}$ & $\begin{array}{l}\text { Fuma- } \\
\text { rate }+ \\
\text { chloram } \\
\text { phenicol } \\
-60 \text { min. }\end{array}$ \\
\hline $\begin{array}{l}9 \cdot 0 \\
9 \cdot 6\end{array}$ & $\begin{array}{l}77 \\
24\end{array}$ & $\begin{array}{c}58 \\
-\end{array}$ & $\begin{array}{l}16 \\
26\end{array}$ & $\begin{array}{l}0.0 \\
-\end{array}$ \\
\hline $\begin{array}{r}17 \cdot 1 \\
6 \cdot 1\end{array}$ & $\begin{array}{r}166 \\
24\end{array}$ & $\begin{array}{r}147 \\
-\end{array}$ & $\begin{array}{l}44 \\
56\end{array}$ & 19 \\
\hline $\begin{array}{l}8.9 \\
2 \cdot 7\end{array}$ & $\begin{array}{l}67 \\
8.9\end{array}$ & 48 & $\begin{array}{l}77 \\
39\end{array}$ & $\begin{array}{l}77 \\
-\end{array}$ \\
\hline
\end{tabular}

of activity and this varied widely with different preparations so that different batches cannot be directly compared. It can be seen, however, from Table 1 that disrupted preparations of organisms grown on Lemco-agar or acetateagar oxidized fumarate more rapidly than the corresponding whole cells. The acetate-oxidizing activity of disrupted preparations was always found to be less than that of the whole organisms and is possibly more easily damaged by the method used for cell breakage than is the fumarate enzyme.

\section{DISCUSSION}

Several workers have shown that cell-free extracts of pseudomonads oxidize intermediates of the tricarboxylic acid cycle, but that whole organisms may have a lag period before a constant rate of oxidation is reached-unless the substrate has been added to the growth medium. This adaptation of whole organisms is prevented by treatments which inhibit protein synthesis, and has been interpreted as due to the synthesis of specific factors concerned with the permeability of the bacteria to these substrates (Barrett \& Kallio, 1953; Kogut \& Podoski, 1953; Clarke \& Meadow, 1959).

In our experiments, fumarate was oxidized without a lag period by suspensions of Mycobacterium smegmatis grown on fumarate and the rate of oxidation was not altered in the presence of chloramphenicol. On the other hand, when the organisms had been grown on Lemco-agar or acetate-agar, there was adaptation to fumarate oxidation during the experimental period, and both the initial rate and the rate in the presence of chloramphenicol were very low. 
The disrupted preparations all oxidized fumarate at a constant rate from zero time, but whereas the rates of fumarate oxidation by disrupted preparations from Lemco-grown and acetate-grown organisms were higher than for the corresponding whole cells, the rate of oxidation of fumarate by disrupted preparations from fumarate-grown organisms was always lower than that for the corresponding whole cells.

We interpret the adaptation to fumarate oxidation by Lemco-grown and acetate-grown organisms as due to the synthesis of a specific fumarate permease which would be already present in cells grown on fumarate. Organisms grown on Lemco-agar had an initial rate of fumarate oxidation, and a rate in the presence of chloramphenicol, no higher than the endogenous rate of oxygen uptake, and we suggest that these cells are initially almost completely devoid of fumarate permease. Organisms grown on acetate had a low but significant initial rate of fumarate oxidation; we suggest that some fumarate permease is present enabling them to adapt more rapidly than Lemcogrown organisms to fumarate oxidation. In addition to the induction of a fumarate permease it is also possible that growth on fumarate or acetate increases the amount of oxidative enzymes present in the cell. If this be so, then it is also possible that this additional enzyme may be more easily destroyed by the treatment used to disrupt the bacteria.

The evidence for an adaptive acetate permease is less clear-cut. The rate of oxidation of acetate by acetate-grown organisms was more than double that of Lemco-grown organisms, but this could have been due to increased production of the oxidative enzymes rather than to increased permease production. It is possible to explain the greater adaptation to acetate oxidation shown by washed suspensions of Lemco-grown and fumarate-grown organisms, as due to permease production, but it is also possible that there was an increase in the amount of oxidative enzymes during the experimental period. It seems likely that the presence of acetate in the growth medium is not essential for Mycobacterium smegmatis to be permeable to acetate. When acetate is present, the adaptation to acetate oxidation may be due to increase in oxidative enzymes and to increase in permeability. These experiments suggest that the impermeability of mycobacteria cannot be ascribed solely to the high lipid content of the outer layers of the cell and that specific permeability factors should be considered.

G. A. Ellard was in receipt of a research training grant from the Department of Scientific and Industrial Research.

\section{REFERENCES}

Clarke, P. H. \& Meadow, P. M. (1959). Evidence for the occurrence of permeases for tricarboxylic acid cycle intermediates in Pseudomonas aeruginosa. J. gen. Microbiol. 20, 144.

Cohen, G. N. \& Monod, J. (1957). Bacterial permeases. Bact. Rev. 21, 169.

Kogut, M. \& Podoskr, E. P. (1953). Oxidative pathways in a fluorescent Pseudomonas. Biochem. J. 55, 800. 
Mrllman, I. \& Youmans, G. P. (1955). The characterization of the terminal respiratory enzymes of the H37 Ra strain of Mycobacterium tuberculosis var. hominis. J. Bact. 69, 320.

Mirner, H. W., Lawrence, N. S. \& French, C. S. (1950). Colloidal dispersion of chloroplast material. Science, 111, 633.

ShILO, M. \& Stanier, R. Y. (1957). The utilization of tartaric acids by Pseudomonads. J. gen. Microbiol. 16, 482.

(Received 19 February 1959) 